\section{CarakaTani \\ Journal of Sustainable Agriculture \\ ISSN 2613-9456 (Print) 2599-2570 (Online)}

\title{
Water Quality and Pollution Index in the Grenjeng River, Boyolali Regency, Indonesia
}

\author{
Tatag Widodo $^{1 *}$, Maria Theresia Sri Budiastuti ${ }^{2}$ and Komariah ${ }^{3}$ \\ ${ }^{1}$ Master Student of Environmental Science, Universitas Sebelas Maret, Surakarta, Indonesia; ${ }^{2}$ Master Program of \\ Environmental Science, Universitas Sebelas Maret, Surakarta, Indonesia; ${ }^{3}$ Department of Soil Science, \\ Faculty of Agriculture, Universitas Sebelas Maret, Surakarta, Indonesia \\ *Corresponding author: tatag.widodo@yahoo.co.id
}

\begin{abstract}
Grenjeng River is one of the irrigation water resources which is currently polluted by waste from industrial, livestock and domestic activities. This study aims to assess the quality and index of water pollution based on physical-chemical and biological parameters in the Grenjeng River, Boyolali Regency. Sampling of river water was carried out in dry and rainy seasons which were taken at three observation stations (upstream, middle stream and downstream). Results from laboratory analysis were compared with water quality standards according to Government Regulation No.82/2001 and quality status was based on the Pollution Index method in accordance with the attachment to Minister of Environment Decree No.115/2003. This study shows that BOD of 53-5.7 mg L-1, COD of 49-510.5 mg $\mathrm{L}^{-1}$ and total coliforms of $540-2,400,000 \mathrm{~mL}$ in dry season have exceeded the quality standard water classes, while in rainy season total coliforms $24,000-240,000 \mathrm{~mL}$ have exceeded the standard water for all water classes. The pollution index of the river water in dry season has reached polluted to extremely polluted levels and the index of the river water in rainy season has reached moderately polluted to polluted levels. This condition shows that the practice of dumping waste into river bodies can directly affect river water quality. The irrigation water source for agricultural must comply with irrigation water quality standards so that is suitable as irrigation water for plants. Environmentally friendly approach is needed to prevent worse pollution, which is done by increasing public awareness and business actors in managing liquid waste by making the integrated wastewater treatment system.
\end{abstract}

Keywords: environmental monitoring, irrigation water quality, water pollution index

Cite this as: Widodo, T., Budiastuti, M. T. S., \& Komariah. (2019). Water Quality and Pollution Index in the Grenjeng River, Boyolali Regency, Indonesia. Caraka Tani: Journal of Sustainable Agriculture, 34(2), 150-161. doi: http://dx.doi.org/10.20961/carakatani.v34i2.29186

\section{INTRODUCTION}

Water is an important part of an ecosystem (Sánchez et al., 2019). Water sources can include lakes, reservoirs, rivers, rainwater, groundwater, etc (Chowdhury and Al-Zahrani, 2015; Xiao et al., 2019). In addition to drinking water needs, water resources also have an important role in various other needs such as irrigation needs of irrigated agricultural land, fisheries and other economic sectors (Tongesayi and Tongesayi, 2015; Sun et al., 2016; Han et al., 2019). Decreasing water quality due to waste disposal also impacts the needs of water as raw material for drinking water and irrigation water, such as the high content of coliform bacteria and heavy metals. Ceoliform bacteria produces an ethionine substance that can cause cancer (Adrianto, 2018). Accumulation of heavy metals on agricultural land can affect plant's growth and can be absorbed by cultivated plants. Heavy metal contamination in cultivated plants can endanger humans if consumed (Pradika et al., 2019). In addition, seasonal differences also have an important influence on changes in water

\footnotetext{
* Received for publication April 9, 2019

Accepted after corrections June 21, 2019
} 
quality. In previous studies, the dissolved oxygen, temperature, biological oxygen demand and total coliforms concentration in rivers were mostly higher in dry season compared to those in rainy season (Cobo et al., 2018; Long et al., 2018; Mukate et al., 2018; Wu et al., 2018; Xu et al., 2018). The quantity and quality of surface water and groundwater can be degraded due to several factors such as increasing population, industrialization activities, urbanization, etc (Jha et al., 2005; Flem et al., 2018). Water quality is very important for determining pollution sources for landuses (Sun et al., 2016; Lima et al., 2018; Xu et al., 2019).

Anthropogenic waste pollution can reduce water quality which is also a very important problem to be resolved immediately (Blettler et al., 2018). At present 420 billion $\mathrm{m}^{3}$ of wastewater is discharged into rivers and lakes and there is 550 billion $\mathrm{m}^{3}$ of polluted fresh water every year worldwide (Ma et al., 2009; Li and Liu, 2018). The supply of clean water in accordance with quality standards plays an important role in the sustainable agricultural sector (Lima et al., 2018; Vakilifard et al., 2019).

An assessment of appropriate water quality requires a method in determining the pollution level. Therefore, the use of water pollution index method is greatly useful in determining the assessment of the initial status of water quality (Effendi et al., 2015; Li et al., 2016). The estimated water pollution index presents parameters and data in a simple manner (Singh et al., 2005; Sun et al., 2016; Zeinalzadeh and Rezaei, 2017). Water quality assessment must also be followed by continuous monitoring of water quality so as to create a healthy water ecosystem (Behmel et al., 2016). River water quality is also strongly determined by chemical, physical and biological parameters and is related to human needs, especially for agricultural purposes and daily consumption (Li, 2014; AznarSánchez et al., 2019).

The Grenjeng River is a water resource used generally to irrigate the surrounding agricultural land. The research related to water quality of the Grenjeng River is limited and therefore there is a possibility to conduct study about the determination of water pollution index of this river. This study aims to determine the water quality of the Grenjeng River based on pollution index method. Water quality management based on the Pollution Index can provide information about water quality and pollution quality standard threshold, especially the water used for irrigating agricultural land.

\section{MATERIALS AND METHOD}

This research was conducted from October 2018 to February 2019. Administratively, the research location of the Grenjeng River was in Sawahan Village, Ngemplak District, Boyolali Regency, Central Java Province. This location needs to be investigated because the Grenjeng River belongs to water source for irrigating agricultural land. The descriptive research was carried out based on observation and laboratory analysis methods. The water sampling technique followed Indonesian National Standard number 6989.57/2008 concerning sampling methods for surface water. Sampling was carried out both in dry and in rainy seasons with one point taken at each point (grab sampling) representing the upstream, middle stream and downstream. Water samples were collected from water bodies using highroute water sampler tool assistance. Each segment consisting of three water samples was taken and then was composited so as to produce a volume of 1 litre of every water sampling points. Water samples were collected and put in dark sample bottle containers. The three water sampling points were determined by considering the terrain to reach the water body and the length of the segment to make it easier to classify activities around the river, making it easier to inventory pollutant sources both point source and diffuse source. Maps of the research location and sample points are presented in Figure 1.

Water samples were measured using physicalchemical and biological parameters for quality standard according to Government Regulation (GR) of Indonesian No.82/2001 concerning Management of Water Quality and Water Pollution Control. Water sample was analyzed in Laboratory of the Center for Environmental Health Engineering and Yogyakarta Disease Control and the GIFU Laboratory Station of Universitas Sebelas Maret, located in Postgraduate Building, $5^{\text {th }}$ Floor, Jl. Ir. Sutami No. 36 A, Kentingan, Surakarta, Central Java, Indonesia. Some parameters tested are presented in Table 1. 
Table 1. Some methods for determining water quality.

\begin{tabular}{lll}
\hline Parameter & Unit & Method \\
\hline $\mathrm{pH}$ & - & SNI 6989.57-2008 \\
Total Dissolved Solids (TDS) & $\mathrm{mg} \mathrm{L}^{-1}$ & In House Method \\
Total Suspended Solids (TSS) & $\mathrm{mg} \mathrm{L}^{-1}$ & In House Method \\
Biological Oxygen Demand (BOD) & $\mathrm{mg} \mathrm{L}^{-1}$ & SNI 6989.72-2009 \\
Chemical Oxygen Demand (COD) & $\mathrm{mg} \mathrm{L}^{-1}$ & SNI 6989.2-2009 \\
Phosphate & $\mathrm{mg} \mathrm{L}^{-1}$ & APHA 2012, Section 4500 PB.5 \& 4500-PD \\
Cadmium & $\mathrm{mg} \mathrm{L}^{-1}$ & SNI 6989.16-2009 \\
Chromium & $\mathrm{mg} \mathrm{L}^{-1}$ & APHA 2012, Section 3500-Cr \\
Plumbum & $\mathrm{mg} \mathrm{L}^{-1}$ & SNI 6989.8-2009 \\
Total coliforms & $\mathrm{mL}$ & APHA 2012, Section 9221-B \\
\hline
\end{tabular}

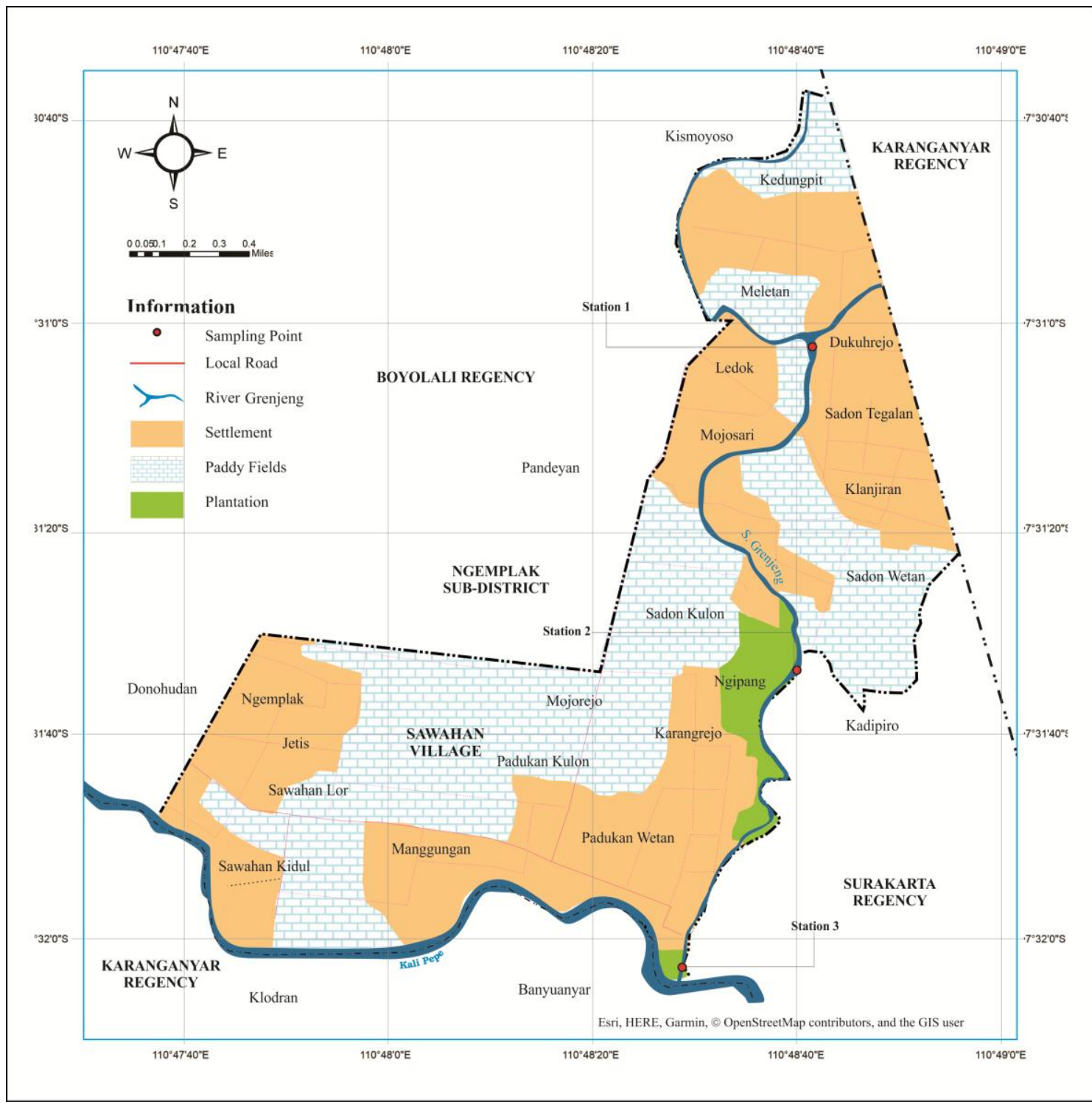

Figure 1. Position of water sampling point at three locations along Grenjeng River, Boyolali District.

\section{Pollution index}

Pollution index is a method or tool that can be used to provide information about water quality
(Effendi et al., 2015; Tanjung et al., 2019) and provide an assessment with a single score on the parameters to interpret water quality ( $\mathrm{Li}$ et al., 2016; Dunca, 2018; Wu et al., 2018). The 
assessment results can be used as references for water quality. The assessment of pollution index and status classification is determined based on Decree of the Minister of Environment No.115/2003 using formula (1) as follows (Nemerow and Sumitomo, 1970).

$$
P I j=\sqrt{\frac{(C i / L i j)_{M}^{2}+(C i / L i j)_{R}^{2}}{2}}
$$

Where:

$$
\begin{aligned}
\mathrm{Lij}= & \begin{array}{l}
\text { concentration of water quality } \\
\text { parameters stated in the water } \\
\\
\text { quality standard }(\mathrm{j})
\end{array} \\
\mathrm{Ci} & \begin{array}{l}
\text { concentration of water quality } \\
\text { parameters survey results }
\end{array} \\
\mathrm{Lpj}= & \text { Pollution Index for designation }(\mathrm{j}) \\
(\mathrm{Ci} / \mathrm{Lij}) \mathrm{M}= & \text { maximum value } \mathrm{Ci} / \mathrm{Lij} \\
(\mathrm{Ci} / \mathrm{Lij}) \mathrm{R}= & \text { average value } \mathrm{Ci} / \mathrm{Lij}
\end{aligned}
$$

Determination of status classifications based on score criteria can be seen in Table 2 as follows.

Table 2. Classification of water quality status based on the pollution index (Minister Environment of Indonesian Decree No.115/2003)

\begin{tabular}{ll}
\hline Score & Criteria \\
\hline $0.0 \leq \mathrm{PIj} \leq 1.0$ & Good water quality \\
$1.0 \leq \mathrm{PIj} \leq 5.0$ & Moderately polluted \\
$5.0 \leq \mathrm{PIj} \leq 10$ & Polluted \\
$\mathrm{PIj}>10$ & Extremely polluted \\
\hline
\end{tabular}

\section{RESULTS AND DISCUSSION}

Water quality

Water is considered polluted if some required parameters have exceeded the maximum limit in accordance with the quality standards according to GR No.82/2001. PH value is a very important parameter to monitor water stability which is closely related to carbon dioxide $\left(\mathrm{CO}_{2}\right)$ and alkalinity which can be interpreted that greater $\mathrm{pH}$ value has more alkali and less carbon dioxide levels (Mackereth et al., 1989; Le et al., 2018; Li and Liu, 2018; Tanjung et al., 2019; Tian et al., 2019). The $\mathrm{pH}$ value ranges from 7 to 8.4 in dry season and from 6.8 to 7 in rainy season (Figure 2). Most aquatic biotas prefer the $\mathrm{pH}$ value of 7 -
8.5 (Effendi, 2003; Setiyono et al., 2008). The results of this study indicate that the $\mathrm{pH}$ values of water in both seasons are still in accordance with the quality standards of $\mathrm{pH} 5-9$.

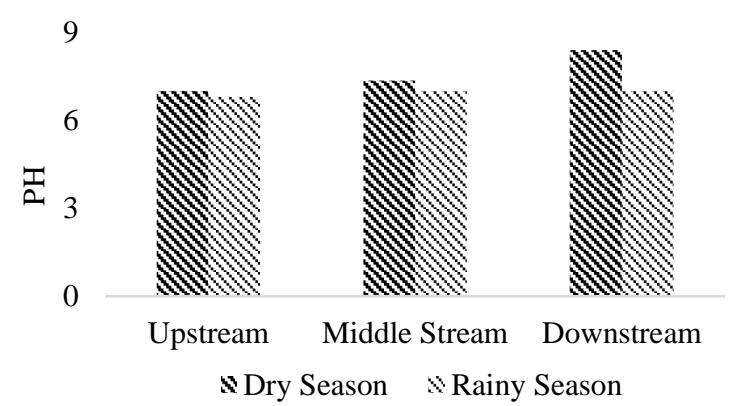

Figure 2. The $\mathrm{pH}$ values of Grenjeng River water in dry and rainy seasons.

TDS in the dry season ranges from 237-1,071 $\mathrm{mg} \mathrm{L}^{-1}$ while in the rainy season ranges from 186$191 \mathrm{mg} \mathrm{L}^{-1}$. TDS is strongly influenced by water flow, so that a decrease in water flow can increase the value of TDS (Salmani and Jajaei, 2016). Waste disposed from industrial activities greatly affects the concentration of TDS (Rohmawati et al., 2016). The results of this study indicate that the value of TDS for the rainy season is still in accordance with the required quality standards which are still below 1,000-2,000 $\mathrm{mg} \mathrm{L}^{-1}$, while for the dry season it is only suitable for class IV water designation which is water that can be used to irrigate crops and / or other designation which requires water quality that is the same as that of use (Figure 3).

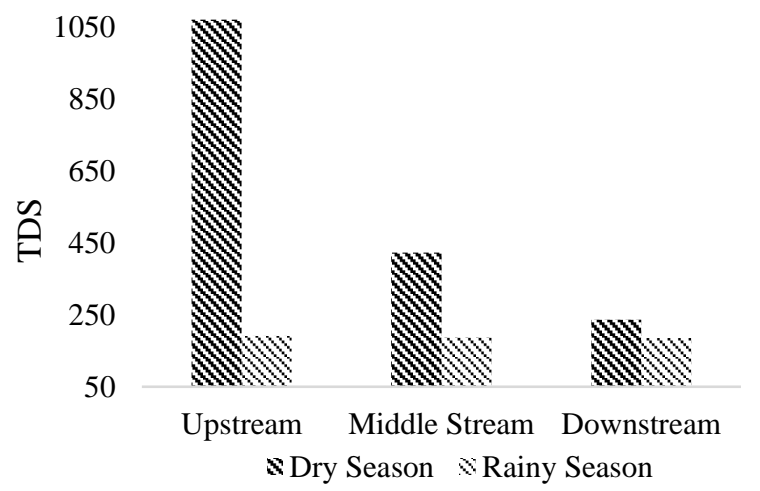

Figure 3. The TDS value of the Grenjeng River water in dry and rainy seasons.

As presented in Figure 4, TSS in the dry season which is $79 \mathrm{mg} \mathrm{L}^{-1}$ (upstream) decreases $13 \mathrm{mg}$ $\mathrm{L}^{-1}$ (downstream), while in rainy season it 
experiences the same thing, which is upstream 22 $\mathrm{mg} \mathrm{L}^{-1}$ decreases when entering the downstream segment, leaving $12 \mathrm{mg} \mathrm{L}^{-1}$ left. Concentration is higher in the upstream area because the area is the meeting point between two rivers and in upstream areas, there are activities such as industry and livestock, and practices of household waste disposal (Mao et al., 2012; Feng et al., 2014; Wang et al., 2018). Water quality pollutants such as TSS are affected by land use activities in the upstream area. Although the pollutants are not toxic, excessive suspended material can inhibit the penetration of sunlight which influences photosynthesis in the waters (Effendi, 2003; Widiadmoko, 2013; Rügner et al., 2019; Tanjung et al., 2019; Tian et al., 2019). Based on the suitability of waters for fisheries, the TSS content of the Grenjeng River water in dry season has little effect on fishery interests but is still suitable for class IV water needs (Effendi et al., 2015; Gashi et al., 2016).

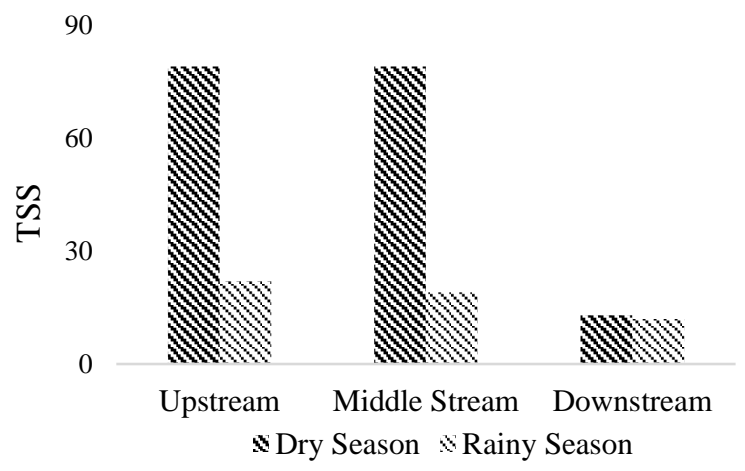

Figure 4. TSS values of the Grenjeng River in dry and rainy seasons.

BOD shows the amount of dissolved oxygen needed by microorganisms in decomposing organic matter during aerobic conditions (Tanjung et al., 2019). The BOD value of the Grenjeng River water are very high in dry season, $53 \mathrm{mg} \mathrm{L} \mathrm{L}^{-1}$ (upstream) and $5.7 \mathrm{mg} \mathrm{L}^{-1}$ (downstream), while in the rainy season, the values experience the same trends, the BOD concentration from upstream $3.6 \mathrm{mg} \mathrm{L}^{-1}$ to leaving only in the downstream segment of $0.7 \mathrm{mg} \mathrm{L}^{-1}$ (Figure 5). The high level of BOD in the upstream segment indicates that there has been polluted organic waste into the river bodies resulting from various activities found in the upstream segment of the Grenjeng River, namely industrial activities, settlements and livestock so that the quality of river water is poor. Based on the BOD level, the pollution level in rainy season is only suitable for class IV, whereas during dry season, the BOD concentration is classified as very high, which exceeds $12 \mathrm{mg} \mathrm{L}^{-1}$, and thus, it is not suitable for all water classes.

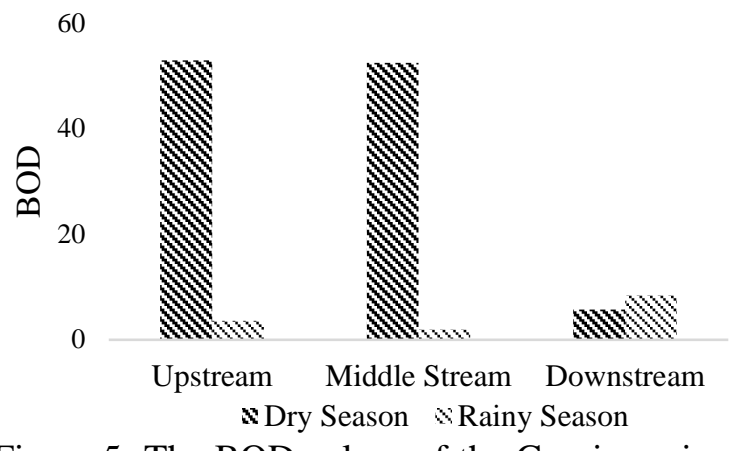

Figure 5. The BOD values of the Grenjeng river in dry and rainy seasons.

COD is a very important parameter for determining water quality that represents the level of organic contamination in water bodies (Zhang et al., 2017; Dhanjai et al., 2018). The COD content of the Grenjeng River in dry season is classified as very high, ranging from $49-510.5 \mathrm{mg}$ $\mathrm{L}^{-1}$, while during rainy season, the COD concentration decreases into $8.4-22.8 \mathrm{mg} \mathrm{L}^{-1}$ (Figure 6). The high COD concentrations commonly occur in rivers in urban areas that are affected by increased waste disposal of domestic, industrial and livestock activities in the water column (Singh et al., 2005; Gashi et al., 2016; Li and Liu, 2018). Based on the analysis, the COD level of the Grenjeng River water in rainy season is still suitable for all water class designations. Meanwhile, the water quality of the Grenjeng River in dry season is classified as very poor and does not match the quality standard because the COD value has exceeded $100 \mathrm{mg} \mathrm{L}^{-1}$.

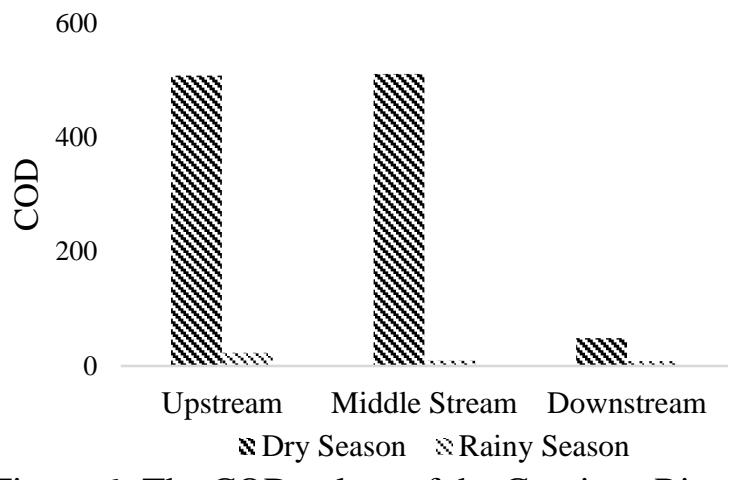

Figure 6. The COD values of the Grenjeng River in dry and rainy seasons. 
Phosphate content in river water bodies can be derived from agricultural, industrial and residential activities (Smith, 2003; Smith et al., 2006; Cao et al., 2016; Colborne et al., 2019). The phosphate content during dry season ranges from 0.4 to $3.6 \mathrm{mg} \mathrm{L}^{-1}$, while in rainy season, it ranges from 1.1-2.6 $\mathrm{mg} \mathrm{L}^{-1}$ (Figure 7). Phosphate waste can indicate nutrient levels and eutrophication in river water (Lettenmaier et al., 1991; Alexander and Smith, 2006; Schindler, 2006; Smith et al., 2006; Wong et al., 2018). Overall the value of phosphate for the whole season is only suitable for class IV water designation. It is only in the downstream segment in dry season that the value is still suitable for water class number III, namely water that can be used for the cultivation of freshwater fish, livestock, water for irrigating crops, or other designations that require water quality that is the same as these uses.

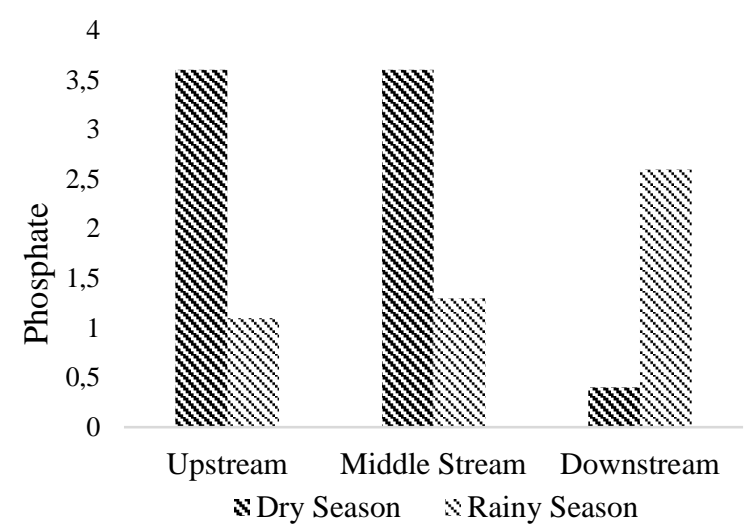

Figure 7. The Phosphate values of the Grenjeng River in dry and rainy seasons.

The content of heavy metal cadmium $(\mathrm{Cd})$ in river water is very dangerous because it is highly poisonous and its presence in the environment is very difficult to degrade naturally (Roberts, 2014; Fauzi and Sunarto, 2015). Cd metal is found in wastewater from industrial processes, which is when exposed to the human body in large quantities, it will damage organs such as the kidneys, testicles, liver, heart, brain, bones and blood system (Pradika et al., 2019). The Cd levels in the Grenjeng River water during dry season and rainy seasons have a static concentration of $<0.0034 \mathrm{mg} \mathrm{L}^{-1}$ (Figure 8). In aquatic ecosystems, contamination of $\mathrm{Cd}$ greatly affects the functioning of ecosystems, the structure and biogeochemical nutrients of water (Hayes et al., 2018; Zhao et al., 2019). Observation of $\mathrm{Cd}$ content the Grenjeng River water during dry season and rainy season is still in accordance with the required quality standards, which are still below $0.01 \mathrm{mg} \mathrm{L}^{-1}$.

$$
0,004
$$$$
\text { 己 }
$$

0,0032
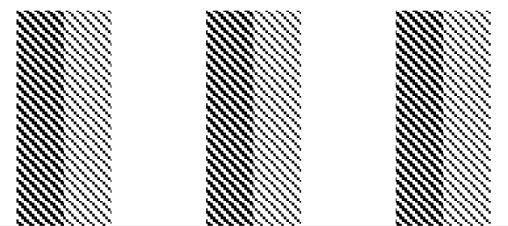

Upstream Middle Stream Downstream

s Dry Season \& Rainy Season

Figure 8. The Cd values of Grenjeng River in dry and in rainy seasons.

Chromium $(\mathrm{Cr})$ is one of the heavy metals that is extremely toxic to aquatic organisms and hazardous to human health (Shadreck, 2014). Cr can contaminate water and soil, and the contamination can be caused by industrial processes, such as the textile industry, leather tanning, paint manufacturing and stainless steel coatings and inorganic fertilizer use (Sembel, 2015; Paul, 2017; Utari et al., 2018; Rohmawati et al., 2016). The Cr content in Grenjeng River water during dry season from upstream to downstream are $0.0014 \mathrm{mg} \mathrm{L}^{-1}$ and increase in rainy season by $0.0213 \mathrm{mg} \mathrm{L}^{-1}$ (Figure 9). The practice of continuously discharging industrial waste into aquatic ecosystems can increase $\mathrm{Cr}$ levels in river water (Wang et al., 2011; Rodríguez et al., 2015; Ali et al., 2016; Capangpangan et al., 2016; Paul, 2017). Observation of $\mathrm{Cr}$ metal content in the Grenjeng River water during dry season, it is still appropriate but in rainy season is only suitable for class IV water designation.

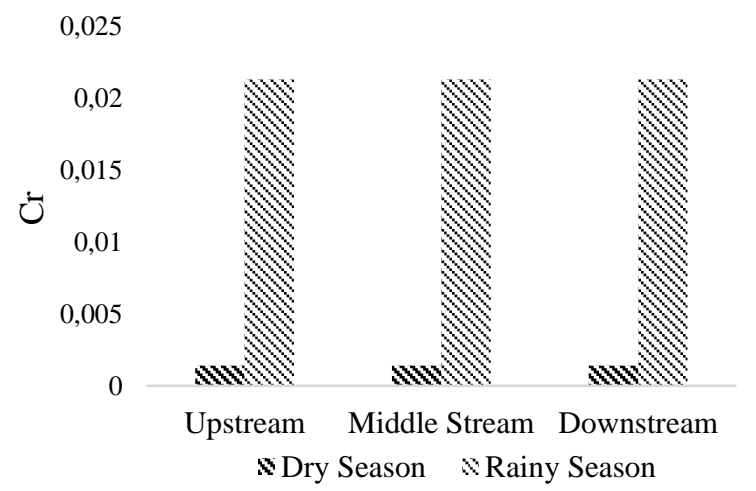

Figure 9. The Cr values of Grenjeng River in dry and rainy seasons. 
Plumbum $(\mathrm{Pb})$ or lead is a heavy metal that is widely used in the paint manufacturing industry and many are found in gasoline to increase octane levels (Said, 2010). The Pb metal content in water of the Grenjeng River during dry season and rainy seasons has a static concentration of $<0.0161 \mathrm{mg}$ $\mathrm{L}^{-1}$ (Figure 10$) . \mathrm{Pb}$ heavy metals are very toxic which can interfere with the nervous system, in which the presence of heavy metals is vastly dangerous for the environment and humans (Guo et al., 2017; Li et al., 2018; Zhou et al., 2018). Based on GR No.82/2001, Pb metals contained in the Grenjeng River water remains within safe limits.

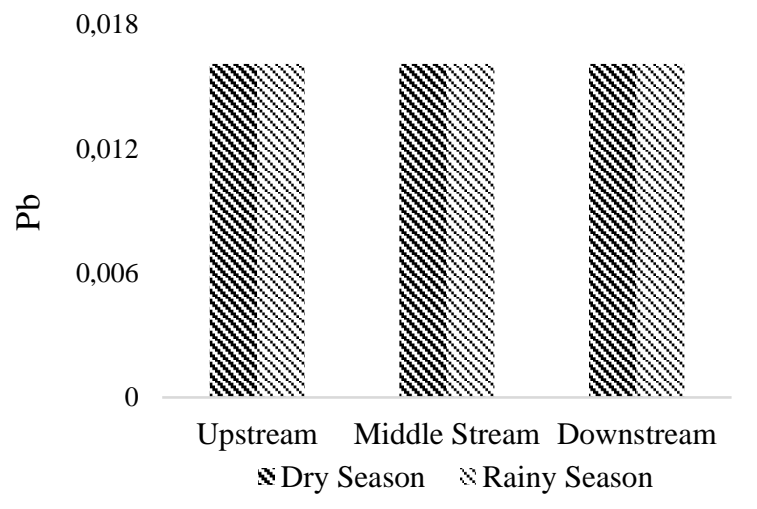

Figure 10. The $\mathrm{Pb}$ values of the water in the Grenjeng River in dry and rainy seasons.

Total coliforms are a group of bacteria commonly found in aquatic environments produced from human fecal waste, animal feces and domestic waste (Messner et al., 2017; Whitehead et al., 2018; Frena et al., 2019). The nature of this bacterium has no taste, smell or color so laboratory analysis must be carried out and the result can be used as a microbiological indicator of a body of water measured in units of quantities mL (Divya and Solomon, 2016; Xue et al., 2018). The total coliform content in Grenjeng River during dry season is very high, ranging from $540-2,400,000 \mathrm{~mL}$ (Figure 11), while the total coliform content in rainy season ranges from 24,000 to $240,000 \mathrm{~mL}$. On the basis of the statistic data from the Ngemplak Subdistrict in 2018, there were 324 pigs, of which 242 were found in Sawahan Village. The high content of total coliform bacteria indicates that this river has been polluted by domestic waste and pig farms that drain liquid waste into river bodies in the upstream to downstream segments so that during dry and rainy seasons, the water is not suitable for water classes I, II, III and IV according to GR No.82/2001.

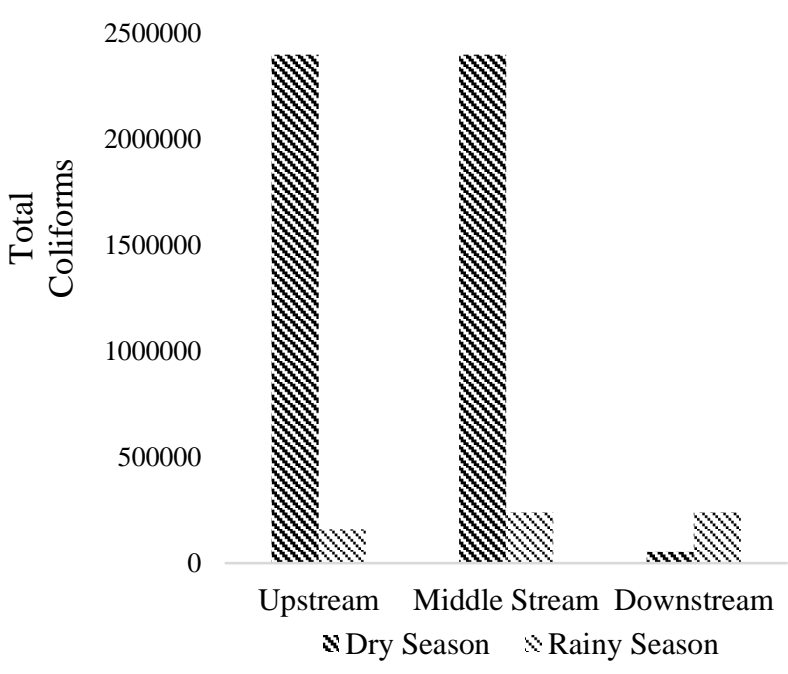

Figure 11. Total Coliform values of the Grenjeng River water in dry and rainy seasons.

\section{Pollution index}

The water quality status of the Grenjeng River in dry season shows that the highest pollution index value is at the upstream to the middle stream and the lowest pollution index is at the downstream. Based on the category of the Grenjeng River water quality status for class I, upstream and middle stream are included in the category of extremely polluted, while the downstream is included in the polluted category. For class II, upstream and middle stream are in the category of extremly polluted, while downstream falls into the category of polluted. For classes III and IV, upstream and middle stream are categorized moderately polluted, as well as the downstream.

The status of the Grenjeng River water quality in the rainy season shows that the highest pollution index value is located at the upstream and middle stream, while the lowest pollution index lies at the downstream. Based on the quality status category, the Grenjeng River water for class I, II, III and IV in upstreams and middle streams are in the moderately polluted category. Meanwhile, the downstream of class I falls into the moderately polluted category, while the downstreams of class II, III and IV are included in the category of polluted.

Based on the calculation of the pollution index value of the Grenjeng River in the upstream area 
special handling is needed to reduce the impact of pollution by liquid waste. During dry and rainy seasons the upstream area is already, moderately to heavily polluted, in which many sewers which drain liquid waste directly into the river water bodies are available. Hence, the wastewater treatment system is needed. Septic tanks are the cheapest and most appropriate application for separating mud, waste from domestic water discharge (Xue et al., 2018; Adhikari and Lohani, 2019). Biogas utilization can also be used as an alternative in managing waste from livestock, so that pollution in the upstream area can be suppressed as much as possible (Abdeshahian et al., 2016; Lu et al., 2018). Prevention is also stated in Regional Regulation of Boyolali District No.13/2015 concerning Environmental Protection and Management in Chapter 6 of the Second Section Control of Water Pollution Control that can be implemented and can be used as the basis for environmental law certainty.

\section{CONCLUSIONS}

The water quality of the Grenjeng River in dry season with BOD, COD and total coliform parameters in the upper and middle parts has exceeded the water quality standard. While in rainy season, it is only total coliform that has exceeded the water standard for all classes of water in the upstream section. The irrigation water source from the Grenjeng River for agricultural land must comply with irrigation water quality standards so that it is suitable as irrigation water for plants. Based on these matters, an environmentally friendly approach is required to prevent worse pollution by increasing public awareness and business actors in managing liquid waste by making the integrated wastewater treatment system.

\section{REFERENCES}

Adrianto, R. (2018). Pemantauan Jumlah Bakteri Coliform Di Perairan Sungai Provinsi Lampung. Majalah Teknologi Agro Industri, 10(1), 1-6. http://ejournal.kemenperin.go.id/ tegi/article/view /3920

Alexander, Richard, B., Smith, Richard, A. (2006). Trends in the nutrient enrichment of U.S. rivers during the late 20th century and their relation to changes in probable stream trophic conditions. Limnology and
Oceanography, 51(1, part 2), doi: 10.4319/ lo.2006.51.1_part_2.0639

Ali, M. M., Ali, M. L., Islam, M. S., \& Rahman, M. Z. (2016). Preliminary assessment of heavy metals in water and sediment of Karnaphuli River, Bangladesh. Environmental Nanotechnology, Monitoring and Management, 5, 27-35. https://doi.org/ 10.1016/j.enmm.2016.01.002

Aznar-Sánchez, J. A., Velasco-Muñoz, J. F., Belmonte-Ureña, L. J., \& Manzano-Agugliaro, F. (2019). The worldwide research trends on water ecosystem services. Ecological Indicators, 99, 310-323. https://doi.org/ 10.1016/j.ecolind.2018.12.045

Behmel, S., Damour, M., Ludwig, R., \& Rodriguez, M. J. (2016). Science of the Total Environment Water quality monitoring strategies - A review and future perspectives. Science of the Total Environment, 571, 1312 1329. https://doi.org/10.1016/j.scitotenv.2016. 06.235

Blettler, M. C. M., Oberholster, P. J., Madlala, T., Eberle, E. G., Amsler, M. L., De Klerk, A. R., \& Szupiany, R. (2018). Habitat characteristics, hydrology and anthropogenic pollution as important factors for distribution of biota in the middle Paraná River, Argentina. Ecohydrology and Hydrobiology, 200, 1-11. https://doi.org/10.1016/j.ecohyd.2018.08.002

Cao, X., Wang, Y., He, J., Luo, X., \& Zheng, Z. (2016). Phosphorus mobility among sediments, water and cyanobacteria enhanced by cyanobacteria blooms in eutrophic Lake Dianchi. Environmental Pollution, 219, 580 587.doi:10.1016/j.envpol.2016.06.017

Capangpangan, R. Y., Pagapong, N. K., Pineda, C. P., \& Sanchez, P. B. (2016). Evaluation of potential ecological risk and contamination assessment of heavy metals in sediment samples using different environmental quality indices - a case study in Agusan River, Caraga Philippines. Journal of Biodiversity and Environmental Sciences.8(1), 2220 - 6663. Retrieved from http://www.innspub.net

Chowdhury, S., \& Al-Zahrani, M. (2015). Characterizing water resources and trends of sector wise water consumptions in Saudi Arabia. Journal of King Saud University - 
Engineering Sciences, 27(1), 68-82. https:// doi.org/10.1016/j.jksues.2013.02.002

Cobo, J. R., Lock, K., Van Butsel, J., Pauta, G., Cisneros, F., Nopens, I., \& Goethals, P. L. M. (2018). Biological impact assessment of sewage outfalls in the urbanized area of the Cuenca River basin (Ecuador) in two different seasons. Limnologica, 71, 8-28. https://doi. org/10.1016/j.limno.2018.05.003

Colborne, S. F., Maguire, T. J., Mayer, B., Nightingale, M., Enns, G. E., Fisk, A. T., \& Mundle, S. O. C. (2019). Science of the Total Environment Water and sediment as sources of phosphate in aquatic ecosystems: The Detroit River and its role in the Laurentian Great Lakes. Science of the Total Environment, 647, 1594-1603. https://doi.org/10.1016/j.scitotenv .2018 .08 .029

Dhanjai, Sinha, A., Zhao, H., Chen, J., \& Mugo, S. M. (2018). Determination of Chemical Oxygen Demand: An Analytical Approach. Reference Module in Chemistry. Molecular Sciences and Chemical Engineering. doi: 10.1016/b978-0-12-409547-2.14517-2

Divya, A. H., \& Solomon, P. A. (2016). Effects of Some Water Quality Parameters Especially Total Coliform and Fecal Coliform in Surface Water of Chalakudy River. Procedia Technology, 24, 631-638. https://doi.org/ 10.1016/j.protcy.2016.05.151

Dunca, A.-M. (2018). Water Pollution and Water Quality Assessment of Major Transboundary Rivers from Banat (Romania). Journal of Chemistry, 2018, 1-8. doi:10.1155/2018/ 9073763

Effendi, H. (2003). Review of Water Quality: for Management of Natural Resources and Aquatic Environment. Yogyakarta: Kanisius Publisher

Effendi, H., Romanto, \& Wardiatno, Y. (2015). Water Quality Status of Ciambulawung River, Banten Province, Based on Pollution Index and NSF-WQI. Procedia Environmental Sciences, 24, 228-237. https://doi.org/ 10.1016/j.proenv.2015.03.030

Fauzi, R. P., \& Sunarto, M. M. (2015). Nostoc commune Vaucher ex Bornet \& Flahault as Fitoremediator of Cadmium Heavy Metals $(\mathrm{Cd}$ (II)). Vol 7, No 2 (2015): EKOSAINS VII(2)
Flem, B., Reimann, C., Fabian, K., Birke, M., Filzmoser, P., \& Banks, D. (2018). Graphical statistics to explore the natural and anthropogenic processes influencing the inorganic quality of drinking water, ground water and surface water. Applied Geochemistry, 88, 133-148. https://doi.org/ 10.1016/j.apgeochem.2017.09.006

Frena, M., Santos, A. P. S., Souza, M. R. R., Carvalho, S. S., Madureira, L. A. S., \& Alexandre, M. R. (2019). Sterol biomarkers and fecal coliforms in a tropical estuary : Seasonal distribution and sources. Marine Pollution Bulletin, 139, 111-116. https://doi. org/10.1016/j.marpolbul.2018.12.007

Gashi, S., Bajmaku, Y., \& Drini, P. (2016). Comparison of some Chemical Parameters of Urban and Industrial Water Discharges Onto the River Lumbardh of Prizren. IFAC-Papers On Line, 49(29), 129-132. https://doi.org/ 10.1016/j.ifacol.2016.11.072

Government Regulations Republic of Indonesia Number 82 year 2001 concerning Management of Water Quality and Water Pollution Control

Guo, Y. M., LIU, Y. G., Li, H., Zheng, A. B., Tan, X. F., \& Zhang, M. M. (2017). Remediation of $\mathrm{Pb}$-contaminated port sediment by biosurfactant from Bacillus sp. G1. Transactions of Nonferrous Metals Society of China (English Edition), 27(6), 1385-1393. https://doi.org/10.1016/S1003-6326(17)60159 $-6$

Han, S., Hu, Q., Yang, Y., Yang, Y., Zhou, X., \& $\mathrm{Li}, \mathrm{H}$. (2019). Response of surface water quantity and quality to agricultural water use intensity in upstream Hutuo River Basin, China. Agricultural Water Management, 212, 378-387. doi: 10.1016/j.agwat.2018.09.013

Hayes, F., Spurgeon, D. J., Lofts, S., \& Jones, L. (2018). Evidence-based logic chains demonstrate multiple impacts of trace metals on ecosystem services. Journal of Environmental Management, 223, 150-164. https://doi.org/10.1016/j.jenvman.2018.05.05 3

Indonesian National Standard Agency. (2008). SNI 6989.57: 2008 Water and Wastewater 
Section 57: Methods for Collecting Surface Water Samples

Jha, R., Bhatia, K. K. S., Singh, V. P., \& Ojha, C. S. P. (2005). Surface Water Pollution. In Water Encyclopedia (3rd ed.). https://doi.org/ 10.1002/047147844x.sw1026

Le, T. T. H., Fettig, J., \& Meon, G. (2018). Kinetics and simulation of nitrification at various $\mathrm{pH}$ values of a polluted river in the tropics. Ecohydrology and Hydrobiology, 19, 54-65. https://doi.org/10.1016/j.ecohyd.2018. 06.006

Lettenmaier, D. P., Hooper, E. R., Wagoner, C., $\&$ Faris, K. B. (1991). Trends in stream quality in the continental United States, 1978-1987. Water Resources Research, 27(3), 327339. doi: 10.1029/90wr02140

Li, D., \& Liu, S. (2018). Detection of River Water Quality. Water Quality Monitoring and Management, 211-220. doi:10.1016/b978-012-811330-1.00007-7

Li, P. (2014). Water Quality Indices. Environmental Earth Sciences, 71(10), 46254628. https://doi.org/10.1007/s12665-014-31 41-9

Li, R., Zou, Z., \& An, Y. (2016). Water quality assessment in Qu River based on fuzzy water pollution index method. Journal of Environmental Sciences (China), 50, 87-92. https://doi.org/10.1016/j.jes.2016.03.030

Li, X., Li, Z., Lin, C. J., Bi, X., Liu, J., Feng, X., $\& \mathrm{Wu}, \mathrm{T}$. (2018). Health risks of heavy metal exposure through vegetable consumption near a large-scale $\mathrm{Pb} / \mathrm{Zn}$ smelter in central China. Ecotoxicology and Environmental Safety, 161, 99-110. https://doi.org/10.1016/j.ecoenv.2018 .05 .080

Lima, G. N., de, Lombardo, M. A., \& Magaña, V. (2018). Urban water supply and the changes in the precipitation patterns in the metropolitan area of São Paulo - Brazil. Applied Geography, 94, 223-229. https://doi.org/ 10.1016/j.apgeog.2018.03.010

Long, D. T., Pearson, A. L., Voice, T. C., Polanco-Rodríguez, A. G., SanchezRodríguez, E. C., Xagoraraki, I., \& Rzotkiewicz, A. T. (2018). Influence of rainy season and land use on drinking water quality in a karst landscape, State of Yucatán, Mexico. Applied Geochemistry, 98 (September), 265277. https://doi.org/10.1016/j.apgeochem.20 18.09.020

Ma, J., Ding, Z., Wei, G., Zhao, H., \& Huang, T. (2009). Sources of water pollution and evolution of water quality in the Wuwei basin of Shiyang river, Northwest China. Journal of Environmental Management, 90(2), 11681177. https://doi.org/10.1016/j.jenvman.2008. 05.007

Mackereth F.J.H., Heron J., Talling J.F. (1989). Water analysis. Fresh Water Biological Association, UK.

Messner, M. J., Berger, P., \& Javier, J. (2017). Total coliform and E. coli in public water systems using undisinfected ground water in the United States. International Journal of Hygiene and Environmental Health, 220(4), 736-743. https://doi.org/10.1016/j.ijheh.2017. 03.003

Minister Environment Decree of Indonesia Number 115 year 2003 Concerning Guidelines for Determining The Quality of Water Status

Mukate, S., Panaskar, D., Wagh, V., Muley, A., Jangam, C., \& Pawar, R. (2018). Impact of anthropogenic inputs on water quality in Chincholi industrial area of Solapur, Maharashtra, India. Groundwater for Sustainable Development, 7, 359-371. https:// doi.org/10.1016/j.gsd.2017.11.001

Nemerow, N. L., \& Sumitomo, H. (1970). Benefits of water quality enhancement report no. 16110 DAJ, prepared for the U.S. Environmental Protection Agency

Paul, D. (2017). Research on heavy metal pollution of river Ganga: A review. Annals of Agrarian Science, 15(2), 278-286. https://doi. org/10.1016/j.aasci.2017.04.001

Pradika, V., Masykuri, M., \& Supriyadi. (2019). Farmer Awareness to the Dangers of Heavy Metal Cadmium (Cd) Pollution due to OverFertilization in Sragen Regency Central Java. Caraka Tani: Journal of Sustainable Agriculture. 34. 76. https://doi.org/10.20961/ carakatani.v34i1.27222

Regional Regulation of Boyolali District Number 13 Year 2015 about Protection and 


\section{Management of The Environment}

Roberts, T. L. (2014). Cadmium and Phosphorous Fertilizers: The Issues and the Science. Procedia Engineering, 83, 52-59. https:// doi.org/10.1016/j.proeng.2014.09.012

Rodríguez, J. A., De Arana, C., Ramos-Miras, J. J., Gil, C., \& Boluda, R. (2015). Impact of 70 years urban growth associated with heavy metal pollution. Environmental Pollution, 196, 156-163. https://doi.org/10.1016/j.envpol.20 14.10 .014

Rohmawati, S. M., Sutarno, S., \& Mujiyo, M. (2016). Kualitas Air Irigasi Pada Kawasan Industri Di Kecamatan Kebakkramat Kabupaten Karanganyar. Caraka Tani: Journal of Sustainable Agriculture, 31(2), 108. https://doi.org/10.20961/carakatani.v31i2.119 58

Rügner, H., Schwientek, M., Milačič, R., Zuliani, T., Vidmar, J., Paunović, M., \& Grathwohl, P. (2019). Particle bound pollutants in rivers: Results from suspended sediment sampling in Globaqua River Basins. Science of the Total Environment, 647, 645-652. https://doi.org/ 10.1016/j.scitotenv.2018.08.027

Sánchez, J. A., Velasco, M. J. F., Belmonte, U. L. J., \& Manzano, A . F. (2019). The worldwide research trends on water ecosystem services. Ecological Indicators, 99, 310-323. doi: 10.1016/j.ecolind.2018.12.045

Said, N. I. (2010). Methods for Removal of Heavy Metals (As, Cd, Cr, Ag, Cu, Pd, Ni, dan Zn) Di in Industrial Wastewater. Jurnal Air Indonesia, 6(2), 136-148. Retrieved from http://ejurnal.bppt.go.id/index.php/JAI/article/ view/2464

Salmani, M. H., \& Jajaei, E. S. (2016). Forecasting models for flow and total dissolved solids in Karoun river-Iran. Journal of Hydrology, 535, 148-159. https://doi. org/10.1016/j.jhydrol.2016.01.085

Schindler, D. W. (2006). Recent advances in the understanding and management of eutrophication. American Society of Limnology and Oceanography, Inc. 51, 356363.

Sembel, D. T. (2015). Toksikologi Lingkungan Dampak Pencemaran dari Berbagai Bahan
Kimia dalam Kehidupan Sehari-hari. Yogyakarta: Andi Offset

Setiyono, O. I., Si, M., \& Sri, I. (2008). Peningkatan kualitas air sungai untuk irigasi persawahan padi dengan sistem "kontrol $\mathrm{pH}$ " di Kabupaten Bengkalis, Riau. Jurnal Air Indonesia. 115-124

Shadreck, M. (2014). Speciation Of Chromium In Soils, Plants And Waste Water At A Ferrochrome Slag Dump In Gweru. IOSR Journal Of Environmental Science, Toxicology And Food Technology, 7(4), 43-49. https://doi. org/10.9790/2402-0744349

Singh, K. P., Malik, A., \& Sinha, S. (2005). Water quality assessment and apportionment of pollution sources of Gomti river (India) using multivariate statistical techniques - A case study. Analytica Chimica Acta, 538(1-2), 355-374. https://doi.org/10.1016/j.aca.2005.0 2.006

Smith, V. H. (2003). Eutrophication of Freshwater and Coastal Marine Ecosystems A Global Problem.Environmental Science and Pollution Research, 10(2), 126-139. https:// doi.org/10.1065/espr2002.12.142

Sun, W., Xia, C., Xu, M., Guo, J., \& Sun, G. (2016). Application of modified water quality indices as indicators to assess the spatial and temporal trends of water quality in the Dongjiang River. Ecological Indicators, 66, 306-312. https://doi.org/10.1016/j.ecolind.20 16.01 .054

Tanjung, R. H. R., Hamuna, B., \& Alianto. (2019). Assessment of water quality and pollution index in coastal waters of Mimika, Indonesia. Journal of Ecological Engineering, 20(2), 87-94. https://doi.org/10.12911/229989 93/95266

Tian, Y., Jiang, Y., Liu, Q., Dong, M., Xu, D., Liu, Y., \& Xu, X. (2019). Using a water quality index to assess the water quality of the upper and middle streams of the Luanhe River, northern China. Science of the Total Environment, 667, 142-151. https://doi.org/ 10.1016/j.scitotenv.2019.02.356

Tongesayi, T., \& Tongesayi, S. (2015). Contaminated Irrigation Water and the Associated Public Health Risks. In Food, Energy, and Water: The Chemistry 
Connection. https://doi.org/10.1016/B978-012-800211-7.00013-2

Utari, R. D., Masykuri, M., \& Rosariastuti, M. M. A. R. (2018). Research Article Enhancing Chromium Phytostabilization Using Chelator ( Agrobacterium sp . I 26, and Manure ) to Support Growth and Quality of Rice ( Oryza sativa L.). SAINS TANAH-Journal of Soil Science and Agroclimatology, 15(2), 83-92. https://doi.org/10.15608/stjssa.v15i1.20818

Vakilifard, N., A. Bahri, P., Anda, M., \& Ho, G. (2019). An interactive planning model for sustainable urban water and energy supply. Applied Energy, 235, 332-345. https://doi. org/10.1016/j.apenergy.2018.10.128

Wang, Y., Yang, Z., Shen, Z., Tang, Z., Niu, J., \& Gao, F. (2011). Assessment of heavy metals in sediments from a typical catchment of the Yangtze River, China. Environmental Monitoring and Assessment, 172(1-4), 407417. https://doi.org/10.1007/s10661-010-1343 $-5$

Whitehead, P., Bussi, G., Hossain, M. A., Dolk, M., Das, P., Comber, S., \& Hossain, S. (2018). Restoring water quality in the polluted TuragTongi-Balu river system, Dhaka: Modelling nutrient and total coliform intervention strategies. Science of the Total Environment, 631-632, 223-232. https://doi.org/10.1016/ j.scitotenv.2018.03.038

Widiadmoko, W. (2013). Physical and chemical water quality monitoring in Hurun Bay waters. Balai Besar Pengembangan Budidaya Laut (BBPBL) Lampung, Bandar Lampung. (in Indonesian).

Wong, W. H., Dudula, J. J., Beaudoin, T., Groff, K., Kimball, W., \& Swigor, J. (2018). Declining ambient water phosphorus concentrations in Massachusetts' rivers from 1999 to 2013: Environmental protection works. Water Research, 139, 108-117. https://doi.org/10.1016/j.watres.2018.03.053

Wu, Z., Wang, X., Chen, Y., Cai, Y., \& Deng, J. (2018). Assessing river water quality using water quality index in Lake Taihu Basin, China. Science of the Total Environment, 612, 914-922. https://doi.org/10.1016/j.scitotenv.
2017.08.293

Xiao, J., Wang, L., Deng, L., \& Jin, Z. (2019). Characteristics, sources, water quality and health risk assessment of trace elements in river water and well water in the Chinese Loess Plateau. Science of the Total Environment, 650, 2004-2012. https://doi.org/10.1016/ j.scitotenv.2018.09.322

Xu, G., Li, P., Lu, K., Tantai, Z., Zhang, J., Ren, Z., \& Cheng, Y. (2018). Seasonal changes in water quality and its main influencing factors in the Dan River basin. Catena, 173, 131-140. https://doi.org/10.1016/j.catena.2018.10.014

Xue, F., Tang, J., Dong, Z., Shen, D., Liu, H., Zhang, X., \& Holden, N. M. (2018). Tempospatial controls of total coliform and E. coli contamination in a subtropical hilly agricultural catchment. Agricultural Water Management, 200, 10-18. https://doi.org/ 10.1016/j.agwat.2017.12.034

Zeinalzadeh, K., \& Rezaei, E. (2017). Journal of Hydrology: Regional Studies Determining spatial and temporal changes of surface water quality using principal component analysis. Journal of Hydrology: Regional Studies, 13, 1-10. https://doi.org/10.1016/j.ejrh.2017.07.0 02

Zhang, F., Xue, H., Ma, X., \& Wang, H. (2017). Grey Prediction Model for the Chemical Oxygen Demand Emissions in Industrial Waste Water: An Empirical Analysis of China. Procedia Engineering, 174, 827-834. https:// doi.org/10.1016/j.proeng.2017.01.229

Zhao, D., Li, J., Lv, L., Zhang, M., Liu, Z., \& An, S. (2019). Effect of cadmium contamination on the eutrophic secondary pollution of aquatic macrophytes by litter decomposition. Journal of Environmental Management, 231, 11001105. https://doi.org/10.1016/j.jenvman.2018. 11.027

Zhou, S., Yuan, Z., Cheng, Q., Zhang, Z., \& Yang, J. (2018). Rapid in situ determination of heavy metal concentrations in polluted water via portable XRF: Using $\mathrm{Cu}$ and $\mathrm{Pb}$ as example. Environmental Pollution, 243, 1325-1333. https://doi.org/10.1016/j.envpol.2018.09.087 